\title{
Access to Medicines Implications of the South Africa Intellectual Property Rights from Publicly Financed Research and Development Act No 51, 2008
}

\author{
Joelle Dountio Ofimboudem* \\ LLD Graduate, University of Pretoria, South Africa
}

"Corresponding author: Dountio Ofimboudem J, LL.D Graduate, University of Pretoria, Private bag X20, cnr Lynnwood Road and Roper Street, Hatfield 0028, South Africa, Tel: +237662987757; E-mail: joelle56310@gmail.com; joelle.dountio@hotmail.com

Received date: May 30, 2016; Accepted date: June 06, 2016; Published date: June 12, 2016

Copyright: ( 2016. Ofimboudem JD. This is an open-access article distributed under the terms of the Creative Commons Attribution License, which permits unrestricted use, distribution, and reproduction in any medium, provided the original author and source are credited.

\begin{abstract}
The Intellectual Property Rights from Publicly Financed Research and Development Act No 51, 2008 (the IPR Act) was passed in 2008 as a result of a request for such a law by the South African DST. According to the DST, such a law was necessary for a number of reasons. Firstly, there was a significant leakage of intellectual property resulting from public-funded research in South Africa into overseas jurisdictions. Secondly, the South African government could not exercise any walk-in (march-in) rights as it was constrained by the fact that different research institutions in South Africa had different approaches to managing intellectual property generated from public-funded research.
\end{abstract}

Keywords: Intellectual property rights; South African DST; Pharmaceutical products

\section{Introduction}

The Intellectual Property Rights from Publicly Financed Research and Development Act No 51, 2008 (the IPR Act) was passed in 2008 as a result of a request for such a law by the South African DST. According to the DST, such a law was necessary for a number of reasons. Firstly, there was a significant leakage of intellectual property resulting from public-funded research in South Africa into overseas jurisdictions [1]. Secondly, the South African government could not exercise any walk-in (march-in) rights as it was constrained by the fact that different research institutions in South Africa had different approaches to managing intellectual property generated from publicfunded research. Thirdly, the value of intellectual property as an instrument of wealth creation was not really appreciated in South Africa. Moreover, the rights of the government, funding institutions, performing institutions and their staff were not defined [2]. As a result, South Africa, unlike other developing countries like Korea, China and India, is not a major player in the global intellectual property domain and has not substantially improved its performance in local or international patenting over the last decade [3]. The DST further noted that an analysis of the patent patterns in South African institutions show very low levels of patenting when compared to other developing countries. For instance, South African academics secure patents at only $2-5 \%$ of the rate of their developed world counterparts, relative to the rate at which they publish their results in the open literature [4]. Meanwhile even though the scientific research and development (R\&D) environment in South Africa is less resourced than that of developed countries like the United States, and South African scientists generate far less scientific research or potentially patentable research, those working in state-funded research institutions often perform equally important research in genetics, microbiology and pharmacology [5]. According to the DST, while South African universities are conducting research and making important discoveries, they are failing to patent and commercialize these inventions, which negatively impacts on the country's ability to contribute substantially in the knowledge economy [4]. To address this lacuna therefore, the DST recommended a better framework and approach in dealing with intellectual property emanating from government-funded research aimed at bringing South African research institutions up to speed with other emerging countries. Given that progress in university research tends to affect industrial innovation in the biomedical sector (particularly biopharmaceutical technology) more than any other [6], this article provides an analysis of the main provisions of the IPR Act with a particular focus on its implications for access to medicines that may be developed out of intellectual property emanating from government-funded research.

\section{Analysis of Key Provisions of the Act}

\section{Objective of the Act}

The Act seeks to ensure that intellectual property emanating from research that is funded by the government is identified, protected, utilized, commercialized and translated into finished goods for social, economic and other benefits [7]. An examination of the key provisions of the Act follows.

\section{Retention of Title, Patenting and Licensing}

To achieve the above-mentioned aim, the IPR Act allows research institutions that are recipients of public funds for research to retain title to intellectual property emanating from such research seek intellectual property protection and ensure the commercialization of such intellectual property. The relevant provision reads as follows: [8] intellectual property rights emanating from publicly financed research and development shall be owned by the recipient. A recipient that prefers not to retain ownership or not to obtain statutory protection... must... notify NIPMO of the decision and the reasons therefor. NIPMO may acquire ownership... should NIPMO decide not to 
acquire ownership it must, in writing, notify the recipient of its decision, the recipient must give the intellectual property creator the option to acquire ownership and obtain statutory protection...

Under the Intellectual Property Rights from Publicly Financed Research and Development Regulations (the Regulations), the desire to make the intellectual property available to the public through open source may serve as enough justification for not protecting inventions emanating from government-funded research. In this case, the recipient merely needs to demonstrate to the National Intellectual Property Management Office (NIPMO) that it is in the public interest that the intellectual property should be placed in the public domain [9]. Such a justification could perhaps be that the invention is a research tool; hence, not seeking intellectual property protection over it will foster innovation [10].

\section{In addition, the IPR Act requires that a recipient: [11]}

...protects intellectual property emanating from publicly financed research and development from appropriation and ensures that it is available to the people of the Republic; ....identifies commercialization opportunities for intellectual property..

The IPR Act defines commercialization to mean the process by which intellectual property originating from publicly financed research is adapted or used to provide any benefit to the society through commercial use on reasonable terms [12]. In most cases, commercialization of intellectual property is achieved through licensing. With respect to licensing, the IPR Act provides that: [13] Preference must be given to non-exclusive licensing; ...to small enterprises; to parties to seek to use the intellectual property in ways that provide optimal benefits to the economy and quality of life of the people of the Republic; exclusive license holders must undertake, where feasible, to manufacture, process and otherwise commercialize within the Republic;...

Before the coming into force of this law, there existed no regulation determining who should hold title to intellectual property originating from publicly financed research in South Africa. This particular provision and the legislation in general therefore provide clarity in this domain.

Interestingly, the above provision puts the public's interest at the center of intellectual property transactions between research institutions and industry by requiring that preference should be given to non-exclusive licenses, and that commercialization should be sought on reasonable terms. This requires research institutions to be mindful of the public's interest in their licensing negotiations with industry. This particular requirement may also be interpreted by courts whenever a case on its interpretation is brought before them to mean, or include reasonable pricing, and could perhaps be a ground for issuing a compulsory license where the public interest so requires.

Again, unlike other similar laws, [14] the IPR Act expressly gives preference to non-exclusive licenses in intellectual property commercialization transactions. The importance of non-exclusive licenses lies in their ability to stimulate competition and lower prices. The alleged disadvantage is that non-exclusive licensees may be discouraged to invest in drug optimization and clinical trials if competitors are merely going to piggyback on their research. Pharmaceutical companies often overcome this risk by obtaining secondary patents on top of the university patent. However, stricter patent standards in South Africa, if eventually adopted, may restrict the availability of secondary patents.
In addition, the IPR Act provides recipients with the option of not seeking intellectual property protection if doing so may prevent, or at the very least, reduce the patenting of research tools. If implemented by researches institutions, this provision will prevent or reduce patent thickets that could be created on research tools and also ensure that these research tools are available to researchers for follow-on research. According to Arti Rai, patent thickets on research tools for a malaria vaccine have been an important barrier to $R \& D$ in a vaccine [15]. A patent analysis commissioned by the Malaria Vaccine Initiative noted that there was great complexity in the patent landscape surrounding just one antigen, MSP-1, likely to be the key to any vaccine that could ultimately be developed, as there exist thirty-four different sets of patents that describe and claim MSP-1, or the production and delivery of this antigen [16]. Though malaria may not be a priority health issue in South Africa, this research blockage may arise in the context of any biomedical research project. Having a provision that gives research institutions the option not to seek intellectual property protection as the IPR Act allows may contribute in reducing the risk of such situations arising.

The use of the phrase reasonable terms in the IPR Act raises concerns as the phrase has been the subject of controversy in the United States where a similar law, namely: the P.L. 96-517 Patent and Trademark Amendments Act 1980, otherwise known as the Bayh-Dole University and Small Business Patent Procedures Act 1980 (the BayhDole Act) has been in force for more than 30 years. While the phrase has been interpreted by United States Courts in non-Bayh-Dole cases to include pricing, funding agencies in the United States have always been reluctant to exercise march-in rights in cases relating to the pricing of medicines developed out of government-funded research [17].

Given this background, and the fact that the DST in the policy document which recommended the adoption of a the IPR Act explicitly cited the United States Bayh-Dole Act as reference, the use of these exact words in the IPR Act without clarification or definition raises questions as to how this may be applied in the South African context [18].

Another important point worth noting is the fact that the Act defines intellectual property to mean: 'any creation of the mind ... capable of being protected by law from use by any other person...' By providing such a broad scope of protectable intellectual property, particularly in the case of patents, the IPR Act fails to recognize the difference between applied research that can benefit from patenting, licensing and commercialization, and upstream research that sometimes does not require exclusivity to promote its exploitation. Patenting upstream research has the potential to discourage a broad range of productive research activity that had previously thrived under a system of free and open academic exchange [19].

\section{Manufacture within South Africa}

The IPR Act mandates that 'Exclusive license holders must undertake, where feasible, to manufacture, process and otherwise commercialize within the Republic' [20] however, in the event that the exclusive licensee is no longer able to commercialize the inventions within South Africa and yet wishes to retain exclusivity, the recipient shall furnish NIPMO with full reasons why it wishes to continue with the exclusive license wherein: [21] NIPMO may request that the exclusive license contemplated... be converted to a non-exclusive license if a recipient fails to furnish the reasons within the period contemplated..., or if NIPMO is not satisfied with such reasons. 
Page 3 of 6

The emphasis on manufacturing in South Africa will ensure that the process of transforming intellectual property into a finished product takes place in the country. This will develop and strengthen the local manufacturing capacity in the country and also create jobs. However, where an exclusive licensee is no longer able to manufacture process and commercialize within South Africa, NIPMO can either authorize manufacture outside South Africa, or require that the license be converted into a non-exclusive one. Considering that the DST in the Intellectual Property Rights (IPR) from Publicly Financed Research Framework Act expressly mentioned that the Act was necessary to, among other reasons, address the assignment of intellectual property arising from government-funded research to overseas companies for commercialization, [22] one wonders whether the Act has actually addressed this.

\section{March-in Right}

\section{Under the IPR Act: [23]}

Each intellectual property transaction must contain a condition to the effect that, should a party fail to commercialize the intellectual property to the benefit of the people ..., the State is entitled to ... conduct reviews of non-commercialized intellectual property in consultation with the recipient ...to ensure that the intellectual property is commercialized. NIPMO may require a recipient to grant a license in any field of use to any person on reasonable terms if, after consultation... the intellectual property is still not being commercialized; or no agreement can be reached with the recipient.

As mentioned above, sometimes exclusive licensees fail to commercialize inventions. The above provision on March-in right could ensure that in such a case a license is granted to a third party who would commercialize the intellectual property on reasonable terms.

Given that all companies are out to make profit, it may be difficult to find a third party (another private company) that will be willing to commercialize the intellectual property if there is little or no prospect of making a profit. This may be addressed by the creation of a specific fund for such situations; providing tax breaks and other forms of benefits as incentives for industry to develop such inventions into finished goods. Alternatively, a law or policy similar to the United States Orphan Drug Act 1983 can be passed to provide special benefits as incentives for industries to invest in developing and commercializing research or inventions that are non-lucrative, hence, unattractive to industry [24]. In order to ensure that whenever the public interest so requires government is held accountable and perhaps compelled to exercise march-in right, the Act or the regulation should have empowered any interested person to request NIPMO or any other competent authority to exercise march-in right. Giving members of the public such an option would not only hold government accountable for failing to exercise this right, but will also serve as a signal to potential licensees that they are accountable to the public in their dealings with intellectual property emanating from publicly funded research or inventions. CSOs in South Africa are very vocal and active in terms of advocacy on the right to access healthcare. This was evident in the struggle for universal access to ARVs for the prevention of mother-tochild-transmission of HIV and the high price of other ARVs between 1998 and 2008 [25]. The constitutional provision of the right of access to healthcare services for all in South Africa could serve as grounds for holding government accountable and requiring it to exercise march-in rights if the need arises [26].

\section{Government-use Right}

\section{The relevant provision reads as follows: [27]}

The recipient determines the nature and conditions of intellectual property transactions... each intellectual property transaction must provide the State with an irrevocable and royalty-free license authorizing the State to use or have the intellectual property used throughout the world for the health, security or emergency needs of the Republic

Under the Regulation, before any proclamation shall be made by Parliament on the right to use the intellectual property, the State must determine the ability of a recipient or any licensee to commercialize the intellectual property; and to meet the specific health, security and other emergency need of the Republic [28].

The fact that this provision expressly mentions that government can exercise the right to use the intellectual property for health reasons presupposes that, although this legislation speaks to research in general, biotechnology and biomedical research are key. Governmentuse right is a very important safeguard because government as a matter of principle has as its object to ensure the wellbeing of its citizens. By providing funds to universities for research, the government is in fact fulfilling part of its mission and should therefore retain rights to all intellectual property transactions that will enable it to continue to secure public welfare. Were this not to be the case, government will be transferring its duties to private industries, which sometimes have little or no consideration for public welfare.

In addition to the government, other research institutions equally involved in government-funded research should also be granted royalty free rights to access and use research results and intellectual property emanating from government-funded research for research, experimental, educational and other non-commercial uses. The United States cases of Madey v Duke University and Association of Molecular Pathology v US Patent and Trademark Office both portray the importance of experimental use exception [29]. In addition, broad research and scientific experimentation rights are permissible under Article 30 of the TRIPS Agreement [30].

Also, very important to note is the fact that, sometimes the number of patents in need of license negotiations by researchers before engaging in a single research project can be challenging, irrespective of the terms on which the licenses are subsequently offered [31]. Although it may be argued that in such a case the government can issue a compulsory license under the South African Patent Act no 57 of 1978, [32] the reality is that this may prove to be a daunting task, hence, the need to have a clear experimental use provision in the Act. Another alternative could be to create a license of right system, with reasonable royalties, for research platform patents.

\section{Disclosure and Reporting}

\section{With respect to disclosure and reporting, the Act provides that: [33]}

... a recipient of funding from a funding agency assesses, [records] and reports on the benefit for society of publicly financed research and development... A recipient must provide effective and practical measures and procedures for the disclosure... and ensure that intellectual property emanating from any publicly financed research and development is appropriately protected before results of such 
research and development are published or publicly disclosed by other means... refer disclosures for which it elects not to retain ownership or not to obtain statutory protection to NIPMO within 30 days or such longer period as may be prescribed, of it making such an election;

\section{With respect to researchers, under the IPR Act, the recipients are required to ensure that: [34]}

...personnel involved with research and development make a disclosure to it within 90 days or such longer period as may be prescribed, of identification... of possible intellectual property and before [it] is made public; assess the intellectual property to determine whether it merits statutory protection and, where appropriate, apply for and use best efforts to obtain statutory protection in its name;

\section{In addition, the recipient shall: [35]}

...report to NIPMO twice a year and as provided for in this Act, on all matters pertaining to the intellectual property..., including all intellectual property from which it elects to obtain statutory protection and the state of commercialization thereof,...; provide NIPMO with full reasons in respect of any intellectual properly that is not commercialized; and in respect of an institution, put in place mechanisms to annually assess, record and report to NIPMO on the benefits for society of... research conducted in that institution.

With respect to disclosure, the fact that research institutions are required to seek protection over intellectual property before publishing will give them ownership of the intellectual property before it is published.

While providing for recipients to seek intellectual property protection over their inventions before publishing, the Act fails to provide a deadline within which such research must be published and also whether the research should be made available on open source in the public domain or not. In view of the fact that the research is publicly funded, it is imperative that research results are made as widely available as possible through open source, at least within the Republic. In addition and as earlier stated, publication delays should be avoided by providing specific timeframes within which research must be published to prevent researchers from working on research that has already been concluded by others. This will save funds, time and other resources. Also, considering that protection and commercialization of research results before publication may be new for most South African researchers, it is important to have very short timelines within which TTOs must secure protection to avoid interference with researchers' work. Early or first publication in a particular research field is very important in the academic world.

Reporting on intellectual property resulting from public-funded research and on its potential benefits to the society is crucial as it informs the government of intellectual property upon which it may need to exercise march-in right or government-use right. Reporting (supposing that such reports are public documents) also informs taxpayers and members of the society at large of the intellectual property and their potential benefit to society which is a form of accountability on the part of research institutions to taxpayers and the government. Reporting on the part of the researcher or the intellectual property creator notifies the recipient of the intellectual property to enable it to report to the government.

\section{Royalty Sharing and Reinvesting}

\section{With respect to royalty sharing, the Act provides that the creator of a particular intellectual property shall receive:}

.... at least 20 per cent of the revenues accruing to the institution from such intellectual property for the first one million rand of revenues, or such higher amount as the Minister may prescribe; and thereafter, at least 30 per cent of the net revenues accruing to the institution from such intellectual property. The benefits must be shared in equal proportions between the qualifying intellectual property creators or their heirs unless otherwise agreed between those creators and the recipient or determined in accordance with institutional policies.

After paying such royalties to the intellectual property creator the recipient may distribute the balance of the revenues as he deems fit, but must apportion part of it to funding more research, the operations of the TTO and cost of obtaining intellectual property protection.

\section{The Technology Transfer Office}

\section{With respect to TTOs, the Act requires recipients to: [36]}

...put in place mechanisms for the identification, protection, development, management of intellectual property, intellectual property transactions and, where applicable, the commercialization of intellectual property and appropriate capacity-building relating thereto... [To ensure this, recipients shall], ...unless determined otherwise... within 12 months of the coming into effect of this Act establish and maintain an office of technology transfer; or designate persons or an existing structure within the institution to undertake the ...obligations of the institution in terms of this Act. Two or more institutions may with the concurrence of NIPMO establish a regional office of technology transfer. NIPMO may, on terms and conditions determined by it, provide assistance to institutions for the establishment of offices of technology transfer.

\section{The functions of the TTOs will be to, among others: [37]}

...develop and implement... policies for disclosure, identification, protection, development, commercialization and benefit-sharing arrangements; receive [and] analyze disclosures... for any commercial potential, the likely success of such commercialization, the existence and form of the intellectual property rights, the stage of development thereof and the appropriate form for protecting those rights; attend to all aspects of statutory protection of the intellectual property [including transactions and commercialization]; refer disclosures to NIPMO; conduct evaluations on the scope of statutory protection in all geographic territories subject to commercialization potential.

The Act further requires that these functions be performed by appropriately qualified personnel having interdisciplinary knowledge, qualifications and expertise in identifying, protecting, managing, and commercializing intellectual property and in intellectual property transactions [38].

One of the criticisms of the practice of technology transfer in the United States is the fact that each research institution sets up and runs a TTO for intellectual property management and technology transfer and the government does not provide financial assistance to run these offices. Therefore, universities rely on patenting and technology commercialization to run these offices [39]. Under the South African 
Act however, this is addressed by the provision that two or more universities can jointly have a single TTO and that a regional TTO can be established.

The Act also provides that NIPMO, as a state agency, will assist university TTOs with coordinating the establishment of a regional office of technology transfer; [40] the development of appropriately skilled personnel for the offices of technology transfer; [41] and also provide financial assistance to TTOs [42]. Hopefully, these important mechanisms provided by the government will spare TTOs from patenting and licensing with no consideration of public interest simply to raise revenue to run and maintain their offices, and also enable the TTOs to actually go for the best mode of achieving the goals of the Act, even if so doing does not necessarily raise immediate financial revenue, or perhaps no financial revenue at all, but is in the public interest [43].

\section{The National Intellectual Property Management Office}

The Act establishes NIPMO within the DST. Under the Act, NIPMO, which is responsible for overseeing and managing intellectual property emanating from government-funded research, must ensure that it has the requisite capacity to consider intellectual property matters referred to it by a recipient and in addition, be responsible for the following: [44]

- Liaising with recipients or any other party it deems fit to determine the viability of obtaining statutory protection for the intellectual property referred to it, where this is in the national interest.

- Concluding any intellectual property transactions including commercialization and manage information in respect of intellectual property.

- Providing incentives to recipients and their intellectual property creators, to reward them for proactively securing protection for intellectual property and commercializing it and, generally, for promoting innovation.

- Providing assistance to institutions with the establishment of offices of technology transfer and related capacity building.

- Providing appropriate standards and best practices in consultation with recipients, without limiting the power of the recipient to act in its own interests in terms of this Act.

- Developing guidelines for intellectual property transactions involving non-South African entities and persons, and manage the implementation of such guidelines.

- Monitoring, evaluating and reviewing the obligations of recipients in terms of this Act.

- Do anything necessary to meet the objects of the Act and to carry out all other functions consistent with those objectives that may be prescribed.

\section{Conclusion}

From the above, one may therefore conclude that the South African IPR Act, though with a few limitations, has to a great extent taken into account important public interest considerations like access to pharmaceutical products that may be developed out of research funded by the government. The reason for this is perhaps that the legal system as a whole, as required by the constitution, is guided by human rights principles that prioritize access to basics like healthcare and related products. Given that it takes several years, typically 12 years, from the moment a molecule is discovered in a scientific laboratory for a potential new therapy to gain approval for use and reach patients, barely eight years after the IPR Act it is still very early to identify a pharmaceutical product developed out of government-funded research for purposes of analyzing whether the provisions of the IPR Act, in terms of access, are being implemented in line with the overall purpose of the Act.

\section{References}

1. Michel AG (2006) Department of Science and Technology 'Intellectual property rights (IPR) from publicly financed research framework' 8.

2. Michel AG (2006) Department of Science and Technology 'Intellectual property rights (IPR) from publicly financed research framework' 18.

3. Michel AG (2006) Department of Science and Technology 'Intellectual property rights (IPR) from publicly financed research framework' 12.

4. Michel AG (2006) Department of Science and Technology 'Intellectual property rights (IPR) from publicly financed research framework' 10-12.

5. Barratt A (2010) 'Lessons from Bayh-Dole: Reflections on the Intellectual Property Rights from Publicly Financed Research and Development Act' 35 Journal for Juridical Science 53.

6. Michel AG (2006) Department of Science and Technology 'Intellectual property rights (IPR) from publicly financed research framework' 10-12.

7. Mowery, David C, Sampat, Bhaven N (2005) 'The US Bayh-Dole Act of 1980 and university-industry technology transfer: A model for other OECD governments?'. Journal of Technology Transfer 30: 115-127.

8. Mowery, DC, Bhaven N (2005) 'The US Bayh-Dole Act of 1980 and university-industry technology transfer: A model for other OECD governments? Journal of Technology Transfer Sec 2(1) 30: 115-127.

9. Mowery, David C, Sampat, Bhaven N (2005) 'The US Bayh-Dole Act of 1980 and university-industry technology transfer: A model for other OECD governments?. Journal of Technology Transfer Sec 4(1)-(4) 30: 115-127.

10. Mowery, David C, Sampat, Bhaven N (2005) 'The US Bayh-Dole Act of 1980 and university-industry technology transfer: A model for other OECD governments?'. Journal of Technology Transfer Sec 12 of the Regulations 30: 115-127.

11. Mowery, David C, Sampat, Bhaven N (2005) 'The US Bayh-Dole Act of 1980 and university-industry technology transfer: A model for other OECD governments?. Journal of Technology Transfer Sec 2(13)(a)-(d) of the Regulations. 30: 115-127.

12. Mowery, David C, Sampat, Bhaven N (2005) 'The US Bayh-Dole Act of 1980 and university-industry technology transfer: A model for other OECD governments?' Journal of Technology Transfer Sec 2(2) (b)-(c) 30: 115-127.

13. Mowery, David C, Sampat, Bhaven N (2005) 'The US Bayh-Dole Act of 1980 and university-industry technology transfer: A model for other OECD governments?. Journal of Technology Transfer Sec(1) 30: 115-127.

14. Mowery, David C, Sampat, Bhaven N (2005) 'The US Bayh-Dole Act of 1980 and university-industry technology transfer: A model for other OECD governments?'. Journal of Technology Transfer Sec 11(1)(a)-(d) 30: 115-127.

15. Namely: the United States P.L. 96-517 Patent and Trademark Amendments Act 1980, otherwise known as the Bayh-Dole University and Small Business Patent Procedures Act 1980 (the Bayh-Dole Act) and the Indian Protection and Utilisation of Public Funded Intellectual Property Bill, 2008.

16. Rai AK (2004) Proprietary Rights and Collective Action: The Case of Biotechnology Research with Low Commercial Value. In: Reichman J, Maskus K (eds.) International public goods and transfer of technology under the globalized intellectual property regime.

17. http://scholarship.law.duke.edu/cgi/viewcontent.cgi? article $=1993 \&$ context=faculty_scholarship

18. Arno PS, Davis MH (2001) 'Why don't we enforce existing drug price controls? The unrecognized and unenforced reasonable pricing requirement imposed upon patent deriving in whole or in part from federally funded research' 75 Tulane Law Review 640-662. 
Citation: Ofimboudem JD (2016) Access to Medicines Implications of the South Africa Intellectual Property Rights from Publicly Financed Research and Development Act No 51, 2008. Intel Prop Rights 4: 150. doi:10.4172/2375-4516.1000150

Page 6 of 6

19. Letter by Ethan Guillen to Dr Boni Mehlomakulu Deputy Director General: Research, Development and Innovation, Department of Science and Technology on 11 August 2009 in response to the Department's request for clarification from Universities Allied for Essential Medicines on some of the criticism it had made on the Draft Regulation and the Act.

20. https:/www.wcl.american.edu/pijip/go/blog-post/uaem-comments-onsouth-african-bayh-dole-analogue-regulations

21. Letter by Ethan Guillen to Dr Boni Mehlomakulu Deputy DirectorGeneral: Research, Development and Innovation, Department of Science and Technology on 11 August 2009 in response to the Department's request for clarification from Universities Allied for Essential Medicines on some of the criticism it had made on the Draft Regulation and the Act Sec 11(d)

22. Letter by Ethan Guillen to Dr Boni Mehlomakulu Deputy DirectorGeneral: Research, Development and Innovation, Department of Science and Technology on 11 August 2009 in response to the Department's request for clarification from Universities Allied for Essential Medicines on some of the criticism it had made on the Draft Regulation and the Act $\operatorname{Sec} 11(1)(f)-(g)$

23. http://www.life-enhancement.com/magazine/article/972-stifle-hungerwith-hoodia

24. CSIR granted an exclusive license on P57 a component of the Hoodia plant to Phytofarm which in turn granted an exclusive license on same to Pfizer to develop and commercialize. Secs 11(2); 14(1)-(4); 11(1)(e) 57.

25. http://www.fda.gov/ForIndustry/ DevelopingProductsforRareDiseasesConditions/ HowtoapplyforOrphanProductDesignation/default.htm

26. Heywood M (2009) 'South Africa's Treatment Action Campaign: Combating law and social mobilization to realise the right to health' Journal of Human Rights Practice 1: 31-34.

27. Heywood M (2009) 'South Africa's Treatment Action Campaign: Combating law and social mobilization to realise the right to health' Journal of Human Rights Practice Sec 27(1)(a) 1: 31-34.

28. Heywood M (2008) 'South Africa's Treatment Action Campaign Combating law and social mobilization to realise the right to health' Journal of Human Rights Practice Secs 11(1)(e); $2(\mathrm{~g})$ of 1: 31-34.

29. e Regulation 8(8)(a).1: 31-34.

30. Hastings L.J. 185 (2010-2011) Invalidating Gene Patents: Association for Molecular Pathology v. U.S. Patent \& Trademark Office, USA

31. Madey V (2002) 307 F 3d 1351 (No. 02-1007) Association for Molecular Pathology v U.S. Patent and Trademark Office No. 09-cV-4515 94 USPQ2d 1683 (S.D.N.Y. 29 March 2010).
32. Barratt A (2010) 'Lessons from Bayh-Dole: Reflections on the Intellectual Property Rights from Publicly Financed Research and Development Act' Journal for Juridical Science 35: 44-46.

33. Eisenberg, RS (1989) "Patents and the Progress of Science: Exclusive Rights and Experimental Use". U. Chi. L. Rev 56: 1017-1086.

34. Barratt A (2010) 'Lessons from Bayh-Dole: Reflections on the Intellectual Property Rights from Publicly Financed Research and Development Act'Journal for Juridical Science 35: Secs 2(2)(a); 5(1)(b) of the Act.

35. Barratt A (2010) 'Lessons from Bayh-Dole: Reflections on the Intellectual Property Rights from Publicly Financed Research and Development Act'Journal for Juridical Science 35: Sec 5(1)(c)-(d) of the Act.

36. Barratt A (2010) 'Lessons from Bayh-Dole: Reflections on the Intellectual Property Rights from Publicly Financed Research and Development Act'Journal for Juridical Science 35: Sec 5(1)(h)-(j) of the Act.

37. Barratt A (2010) 'Lessons from Bayh-Dole: Reflections on the Intellectual Property Rights from Publicly Financed Research and Development Act'Journal for Juridical Science 35: Secs 5(1)(a); 6(1)-(3) of the Act.

38. Barratt A (2010) 'Lessons from Bayh-Dole: Reflections on the Intellectual Property Rights from Publicly Financed Research and Development Act'Journal for Juridical Science 35: Sec 7 (2)(a)-(h) of the Act.

39. Barratt A (2010) 'Lessons from Bayh-Dole: Reflections on the Intellectual Property Rights from Publicly Financed Research and Development Act'Journal for Juridical Science 35: Sec 7(1) of the Act.

40. Skype interview with Richard Jennings, Deputy Director of Cambridge Enterprise, on 23 September and 12 November 2013).

41. Barratt A (2010) 'Lessons from Bayh-Dole: Reflections on the Intellectual Property Rights from Publicly Financed Research and Development Act'Journal for Juridical Science 35: Sec 6(4)(b)(ii).

42. Barratt A (2010) 'Lessons from Bayh-Dole: Reflections on the Intellectual Property Rights from Publicly Financed Research and Development Act'Journal for Juridical Science 35: Sec 6(4)(b)(iii).

43. Barratt A (2010) 'Lessons from Bayh-Dole: Reflections on the Intellectual Property Rights from Publicly Financed Research and Development Act'Journal for Juridical Science 35: Sec 6(4)(b)(i).

44. Barratt A (2010) 'Lessons from Bayh-Dole: Reflections on the Intellectual Property Rights from Publicly Financed Research and Development Act'Journal for Juridical Science 35: Sec 9(1)-(5). 